\title{
Evidence for a differentiated chromosomal race north of classical south European refuge areas in the garden dormouse Eliomys quercinus
}

\author{
Roland Libois • Maria Graça Ramalhinho • René Rosoux
}

Received: 5 October 2011 / Accepted: 12 June 2012

(C) Mammal Research Institute, Polish Academy of Sciences, Białowieża, Poland 2012

\begin{abstract}
The dormouse Eliomys quercinus is a forest rodent undergoing long periods of winter hibernation. The species presents a surprisingly large diversity of chromosomal races, which geographic distribution was shown recently to predate the Pleistocene glaciations. Previously reported data on the karyotypes of the garden dormouse in France come from the northeast of the country, where the $2 \mathrm{~N}=50$ race occurs. New data are presented from specimens trapped near the Atlantic coast (departments of Vendée and Charente-Maritime), in the Pyrenees, the Alps and in the Massif Central. The French Alpine chain, close to the Italian border, is inhabited by the $2 \mathrm{~N}=54$ race. A karyotype with $2 \mathrm{~N}=48$ chromosomes, of Iberian type, is found north of the Pyrenees, near the central Atlantic coast and also in the south of the Massif Central, whereas the $2 \mathrm{~N}=50$ race occurs in the north of the massif. A
\end{abstract}

Communicated by: Mieczyslaw Wolsan

\section{R. Libois $(\square)$}

Unité de recherches zoogéographiques, Bâtiment 22,

Université de Liège,

Boulevard du rectorat, 27,

4000 Liège, Belgium

e-mail: roland.libois@ulg.ac.be

M. G. Ramalhinho

CESAM (Faculdade de Ciências),

Museum National de Historia Natural e Ciência,

Universidade de Lisboa,

Rua da Escola Politécnica, 58,

1268-102 Lisbon, Portugal

M. G. Ramalhinho

e-mail: gramalhinho@fc.ul.pt

R. Rosoux

Museum d'Histoire Naturelle,

rue Marcel Proust, 6,

45000 Orléans, France

R. Rosoux

e-mail: rrosoux@ville-orleans.fr hybrid between these two races $(2 \mathrm{~N}=49)$ was found in Vendée. These facts reveal that neither the Pyrenees nor the Alps constitute a biogeographic barrier to the dormouse and strongly suggest that the present population of northern France derives from a postglacial recolonisation movement initiated in the southernmost regions of France or in the Rhône valley.

Keywords Garden dormouse · France · Distribution · Karyotypes $\cdot$ Hybridization

\section{Introduction}

The postglacial recolonisation patterns of forest rodents have been extensively studied in recent years (Deffontaine et al. 2005; Michaux et al. 1998, 2004; Nieberding et al. 2005). These studies demonstrated that most rodents survived the cold periods of the Quaternary in temperate southern refuges including Spain, Italy and the Balkans. This pattern may not be applicable to species displaying winter hibernation, and increased tolerance to cold temperatures, for which more northerly refuge areas might be expected. The garden dormouse (Eliomys quercinus) is a useful model species to test this hypothesis, sharing an ecological niche with rodents for which data are available, but having extensive periods of winter hibernation. Moreover, it has been previously shown that this species exhibits allopatric differentiated karyotypic races (Cristaldi and Canipari 1976; Filippucci et al. 1988b; Zima et al. 1994). The differentiation of these karyotypic races predates the Quaternary period and likely took place about 4 million years ago (Perez et al. 2012). During the Pliocene period, a rather warm climate prevailed in Europe (Fauquette et al. 1998), and the Eliomys genus was well distributed in Spain, in southern France, in Greece (Kowalski 2001), in northern Italy (Verona: Sala 1996) and in Sardinia (Kotsakis 1986). Thus, the dormouse 
chromosomal races were confronted to the contrasted climatic conditions that started with the Quaternary period.

This dormouse is currently found in forests of pine, larch and oak and in mixed coniferous and deciduous woods, orchards, vineyards, parks and villages, from sea level to the upper tree limit (currently to 2,300 $\mathrm{m}$ in the Alps or the Pyrenees, but still higher in southern Spain or Morocco at 2,500 and 2,800 m, respectively). It also lives in Mediterranean scrub, if not too dense, and utilises stony or rocky environments, colonising old buildings, ruins, dry stone walls as well as mountain boulders, karstic habitats, old quarries or cliffs. Some populations live in forested sand dunes (Marismas del Guadalquivir; northern Belgium). Throughout its distribution, it is found in close proximity to humans, in farms, huts, storehouses or attics (after Ognev 1963; Storch 1978 and personal observation).

The systematics of the genus Eliomys is still a question of debate and long-standing conflicting opinions. No less than 28 names have been proposed since 1766 (Holden 1993), and Miller (1912) recognised five extant species in Europe alone, whereas Ellerman and Morrison-Scott (1951) reduce the number of species to two: E. quercinus from Europe and north Africa and Eliomys melanurus from "south-west Asia" (i.e. the near-east). More recently, various authors have considered that a single species, formed by three distinct lineages, or subspecies, is present in Europe: the "quercinus", "lusitanicus" and "melanurus" lineages (Corbet 1978; Kahmann and Thoms 1981; Niethammer 1959; Storch 1978). These lineages are distinguished on the basis of the coloration pattern of the tail. However, this viewpoint is not universally accepted (Nadachowski et al. 1978; Nader et al. 1982). From karyological analyses and electrophoretical comparisons, Filippucci et al. $(1988$ a, c) concluded that two distinct species existed, i. e. $E$. quercinus in Europe, including the Mediterranean islands, and E. melanurus in northern Africa ( $N=46$ chromosomes) and the near-east ( $N=48$ chromosomes).

Krystufek and Kraft (1997) collected skull samples throughout the north African, near-eastern and west European parts of the distribution of the dormouse and concluded that animals from the near-east are distinct from all the other ones. The border between quercinus' and melanurus' distribution ranges lies somewhere in Libya, between Cyrenaica and Tripolitana. Therefore, the Eliomys genus contains two species, but the question of their African distribution is still under debate.

The existence of different morphotypes and cytotypes in the European garden dormouse has long been recognised. However, as cytological studies progressed, it became evident that these morphotypes did not fully correspond to the karyological characteristics (Cristaldi and Canipari 1976; Krystufek and Kraft 1997).

In Europe, four chromosomal races have been found. One, with $2 \mathrm{~N}=48$ is distributed in the Iberian peninsula, central and southern Italy, Croatia (Vujosevic et al. 1993), Romania
(Murariu et al. 1985), Russia (Graphodatsky and Fokin 1993) and the western Mediterranean islands, except Sardinia. The animals with 50 chromosomes are distributed from northeastern France to Germany, Austria and Czech Republic and are present in Sardinia (Cristaldi and Canipari 1976; Zima et al. 1994, 1997). A Swiss form with $2 \mathrm{~N}=52$ was first reported by Matthey and Renaud (1937) and its presence confirmed later by Renaud (1938). Unfortunately, the location of the capture site (s) of the specimens analysed was not given. However, it seems that Renaud trapped small rodents in the "district de Lausanne" (op. cit., p. 350). Later, this form has been found in the Alps, from the Valle d'Aosta to the eastern part of the chain (Cristaldi and Canipari 1976; Filippucci et al. 1988b; Ramalhinho and Libois 2005). Another form with $2 \mathrm{~N}=54$ ranges from Liguria, near the Mediterranean coast, to the Valle d'Aosta and the upper Rhône valley (Cristaldi and Canipari 1976; Filippucci et al. 1988b; Zima et al. 1994).

Until now, there have been no reports of contact or hybrid zones between these different races, with the exception of the region of the Gran Paradiso where Cristaldi and Canipari (1976) observed the sympatry of both Alpine forms (52 and 54 chromosomes).

Surprisingly, in France the few data published have all reported a diploid number of $2 \mathrm{~N}=50$ chromosomes, except in Corsica where it is 48 (Italian race; Table 1; Orsini 1987). However, all the animals studied were trapped in the central and north-eastern part of the country, where a diploid number of 50 would be expected given the distribution of this chromosomal race in neighbouring countries (Fig. 1). No analysis has been done on dormice living either on the northern slopes of the Pyrenees nor in the French part of the Alpine massif, i.e. in the vicinity of other chromosomal races.

Recently, the postglacial recolonisation of Western Europe has been studied in several species, showing the significance of the Alps and of the Pyrenees on their phylogeographical pattern (Hewitt 1999; Michaux et al. 1998; Taberlet et al. 1998). This paper presents new information on the French distribution of Eliomys chromosomal races and discusses the role of these mountain chains as biogeographical barriers.

\section{Methods}

Animals were live trapped in LFA Sherman traps $(7.5 \times 8.9 \times$ $22.9 \mathrm{~cm}$ ) baited with a sardine and flour mixture in southern France, from the Atlantic coast to the Alps, and cytologically analysed. Microscope slides for observation of the chromosomes in somatic metaphases were prepared by direct treatment of the bone marrow (Baker et al. 1982). The G banding was obtained using Seabright's technique (1971). The diploid number $(2 \mathrm{~N})$ and the morphological chromosome characteristics were analysed using a Leica Q500 image analyser and Leica Chantal and Qwin software. 


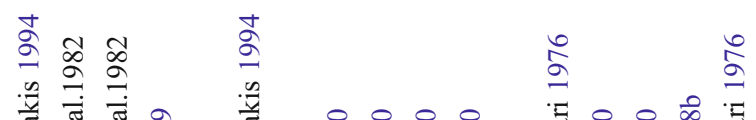

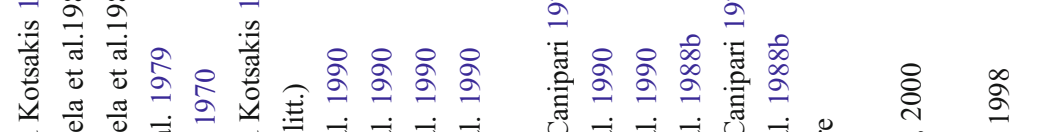

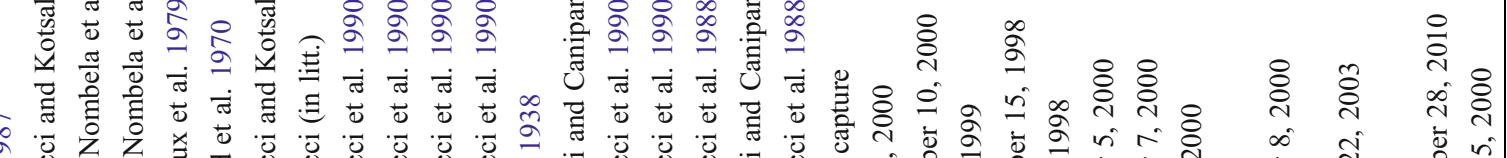

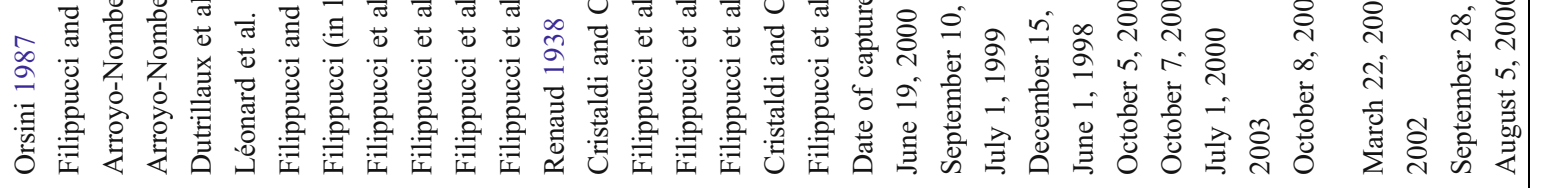

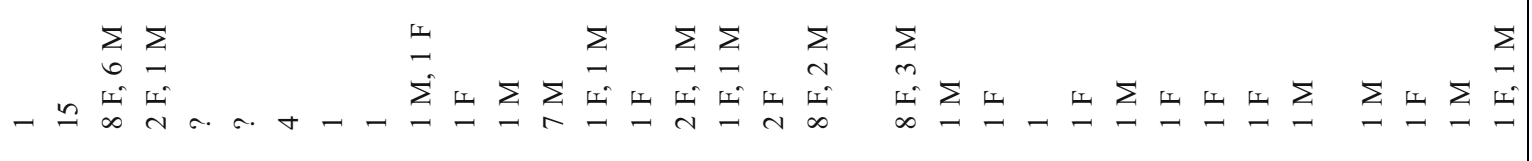

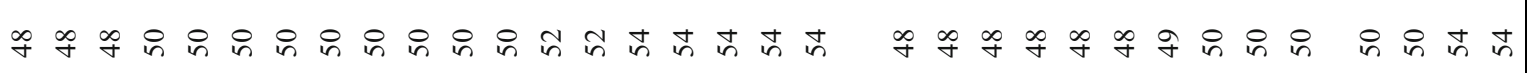

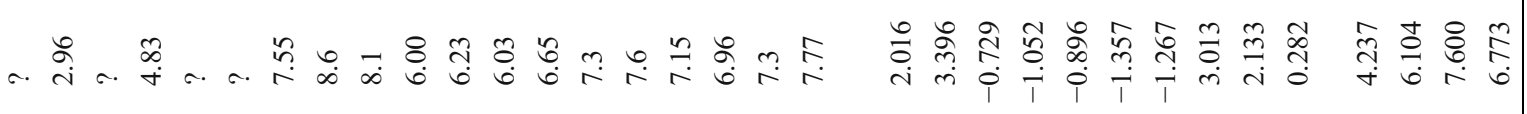

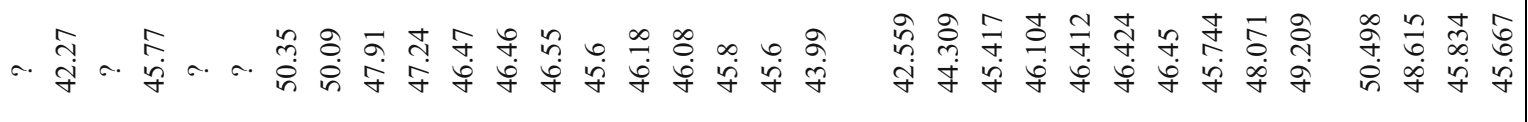

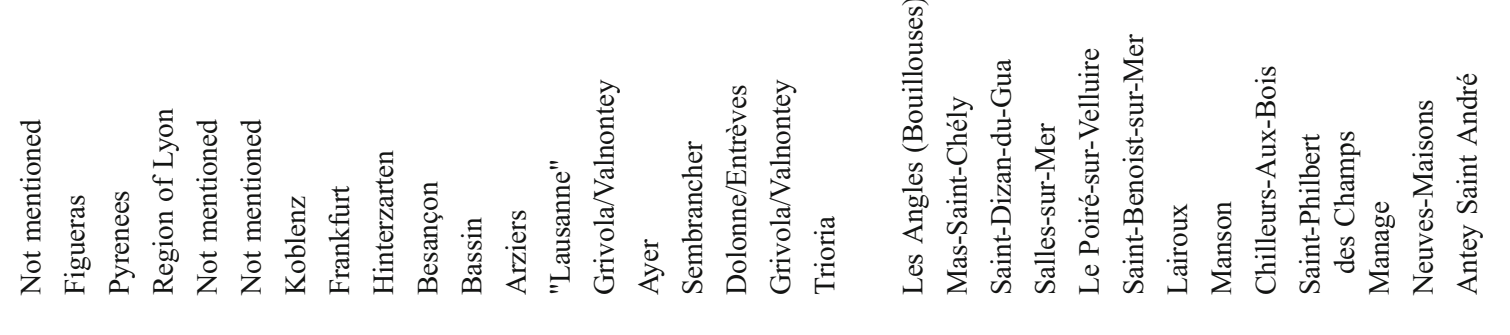

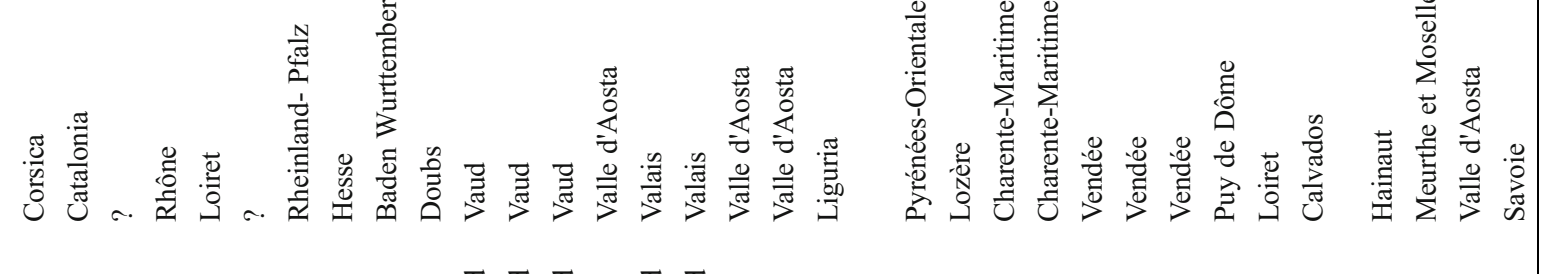

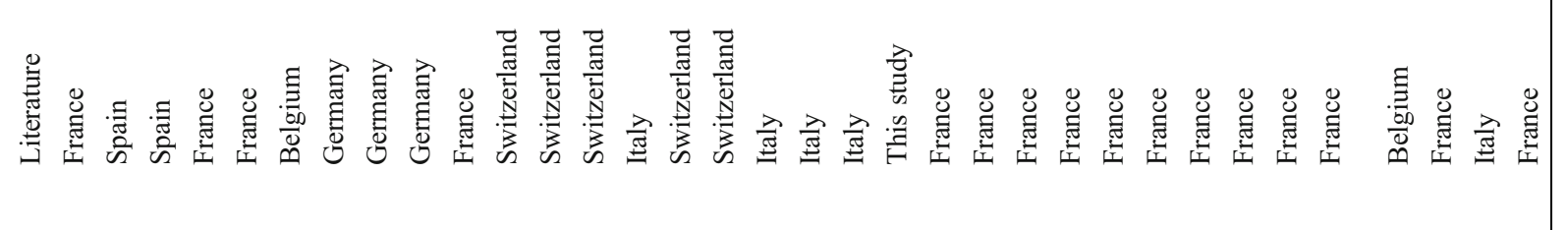
$\varangle \infty$ U 


\section{Results}

The location of the capture sites, the number of animals and their diploid number are presented in Table 1 and mapped in Fig. 1. Four different chromosomal races were observed in the garden dormice trapped in France.

The 25 Pyrenean animals (Table 1), one from Lozère (Causse Méjean) and those living near the Atlantic coast in the departments of Charente-Maritime and Vendée, were all characterised by a 48-chromosome karyotype. This was composed of four pairs of large-sized subtelocentric, eight pairs of metacentric, ten pairs of submetacentric and one pair of acrocentric chromosomes, where the $\mathrm{X}$ chromosome is a large metacentric and $\mathrm{Y}$ is punctiform (Iberian race) (Arroyo-Nombela et al. 1982; Diaz de la Guardia and RuizGirela 1979). In contrast, the "Italian" race, as found in Corsica, also has $2 \mathrm{~N}=48$, but is characterised by three pairs of acrocentric autosomes (Cristaldi and Canipari 1976; Filippucci et al. 1988b; Gornung et al. 2010; Vujosevic et al. 1993).

A diploid number of 50 is found in one animal from Normandy, in another from Lorraine (near Nancy), a third from near Orléans and in a fourth from the Massif Central, near Clermont-Ferrand. The karyotype is the same as above, but with two more pairs of acrocentric chromosomes in place of one pair of submetacentric (Arroyo-Nombela et al. 1982; Filippucci et al. 1990; Leonard et al. 1970).

All the animals trapped in the Alps, between the Mont Blanc massif and the Mediterranean coast, had a diploid number of 54 chromosomes (south Alpine race). Their karyotype is composed of four pairs of large subtelocentric, seven pairs of metacentric, eight pairs of submetacentric and seven pairs of acrocentric chromosomes. The same chromosomal pattern was observed by Cristaldi and Canipari (1976) and Filippucci et al. (1988b).

A female from Lairoux (Vendée) had a karyotype of $2 \mathrm{~N}=$ 49 chromosomes (Fig. 2). Its autosomes comprised four pairs of large subtelocentric, eight pairs of metacentric, nine pairs of submetacentric, one pair of acrocentric chromosomes and three unpaired chromosomes: one submetacentric (A in Fig. 2) and two acrocentric ones (B and $\mathrm{C}$ in Fig. 2). These latter had a banding pattern corresponding clearly to each of the arms of the unpaired submetacentric chromosome.

\section{Discussion and conclusions}

The occurrence of the south Alpine race $(2 \mathrm{~N}=54)$ on the Italian slopes of the western Alps has already been demonstrated by Cristaldi and Canipari (1976) and Filippucci et al. (1988b). The present data show that its French distribution corresponds to the Italian one, extending at least from the 
Fig. 1 Distribution of the chromosomic races of the garden dormouse, E. quercinus, in France and in neighbouring countries. Race with 48 chromosomes "Iberian" (squares), race with 48 chromosomes "Italian" (cross inside a square) (Corsica), race with 50 chromosomes (circles), race with 52 chromosomes (triangles) and race with 54 chromosomes (diamonds). The grey star indicates where the hybrid dormouse was trapped. Symbols in grey, data from the literature; in plain, data from this study. The large symbols refer to an imprecise sampling location (see Table 1). The broken lines tentatively delimit the hybrid zone (see main text). Please refer to Table 1 for digit vs letter numbers

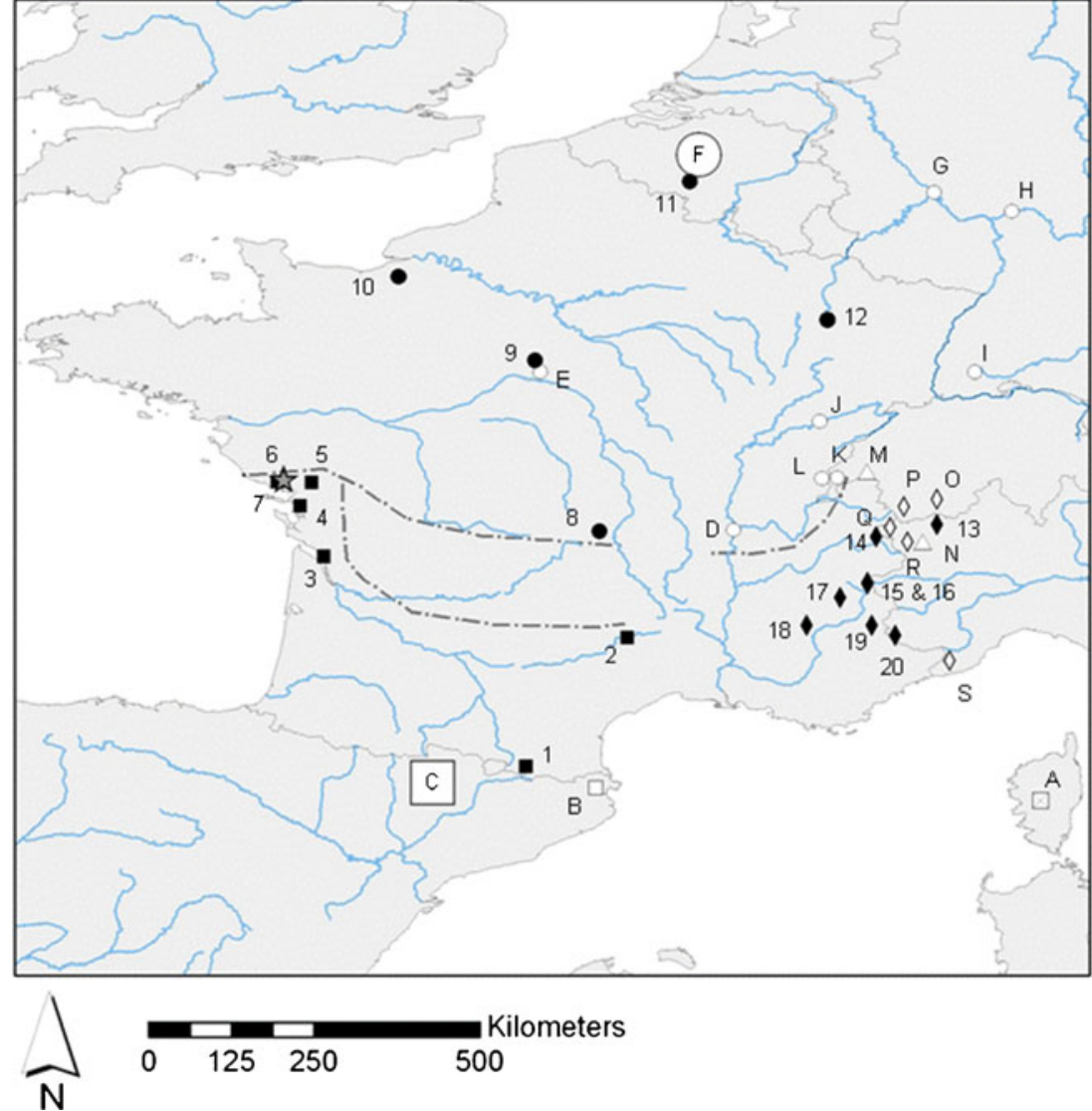

Massif of Mont Blanc to Mercantour, along the Italian border and from the Italian border to the south-western part of the department of Hautes-Alpes. Our data from the French side of the Alps, reported here for the first time, suggest that the Alps do not act as a biogeographic barrier for the dormouse, although more data from the western extension of the south Alpine race are needed.

Similarly, the presence of animals with an "Iberian" karyotype seems well established, not only along the
Atlantic coast up to La Rochelle but also in the southern part of the Massif Central. Therefore, it may be assumed that the present populations of south-western France might have survived in situ (Kowalski 2001). Alternatively, these populations may be derived from a postglacial recolonisation movement initiated either in the Iberian Peninsula or more probably from the Mediterranean coast or the Basque region in southern France, where some deciduous forests remained, even during the most severe frosts of the last glaciation
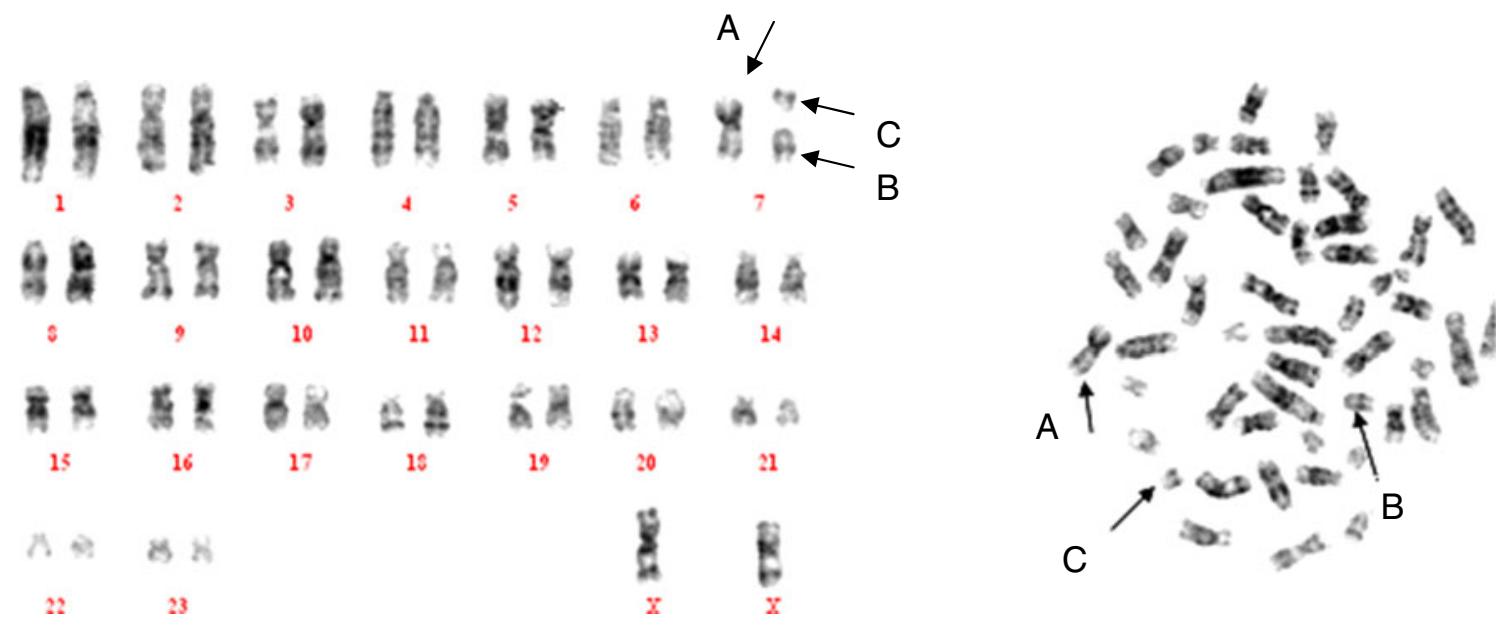

Fig. 2 Metaphase chromosomes and G-banded karyotype from a female 2N=49. Hybride from Lairoux (Vendée). The chromosomes are numbered according to the morphology of $2 \mathrm{~N}=48$ and $2 \mathrm{~N}=50$. One of the chromosomes (7) has fissioned originating from two acrocentrics 
(Antoine et al. 1999; Blondel 1995). Indeed, fossil garden dormouse remains have been found throughout the Middle and Upper Pleistocene in Spain and in southern France (Chaline 1972; Kowalski 2001; Lopez-Garcia et al. 2007). In other forest rodents, the Pyrenees did not constitute a biogeographical barrier, either when they moved from the south to north (Apodemus sylvaticus: Michaux et al. 2003; Myodes glareolus: Deffontaine et al. 2005) or from north to south (Apodemus flavicollis: Michaux et al. 2004).

The female from Lairoux $(2 \mathrm{~N}=49)$ is a hybrid animal between the chromosomal races $2 \mathrm{~N}=48$ (Iberian) and $2 \mathrm{~N}=$ 50. This is the first time that a hybrid between two chromosomal races of the garden dormouse has been reported. The existence of fertile hybrids between chromosomal races was reported in several other species including the house mouse (Mus domesticus) in Madeira (Britton-Davidian et al. 2007), Mus minutoides in South Africa (Veyrunes et al. 2010) and the common shrew (Sorex araneus) in Siberia (Polyakov et al. 2011). The existence of a hybrid with $2 \mathrm{~N}=49$ shows that the two races $2 \mathrm{~N}=50$ and $2 \mathrm{~N}=48$ can interbreed. The race $2 \mathrm{~N}=50$ therefore probably results from a single Robertsonian rearrangement involving a submetacentric chromosome of a $2 \mathrm{~N}=48$ Iberian karyotype. The enzymatic data of Filippucci et al. (1988c) similarly suggest that the Iberian race $2 \mathrm{~N}=48$ is more closely related to the $2 \mathrm{~N}=50$ race than to the Italian race $2 \mathrm{~N}=48$. However, the western mtDNA (cytb) lineage $(2 \mathrm{~N}=50)$ is closer to the Alpine lineages than to the Iberian one (Perez et al. 2012).

The presence in Lairoux of an animal with $2 \mathrm{~N}=49$ chromosomes indicates that a hybrid zone exists in the south of the department of Vendée, i.e. that some populations of garden dormice with $2 \mathrm{~N}=50$ (northern race) must live in the vicinity. Extrapolating the geographical data so far obtained, it seems that the northern race reaches the south of Vendée and continues approximately from Niort to Limoges, Clermont-Ferrand and Lyon, as defined by the upper line in Fig. 1. On the other hand, the Iberian race extends at least to southern Vendée, and south of a line running roughly from Niort to Bergerac, Cahors, Rodez and Florac (as defined by the lower line in Fig. 1). There is thus support for the existence of a hybrid zone situated between these two lines.

The northern race of garden dormouse is currently located north of the 46th parallel where tundra, a hostile environment for the species, predominated during the last ice age (Blondel 1995). Similarly, the dormouse was probably absent from central Europe from Early Pleistocene to the Holocene and recolonised these regions recently during the sub-boreal time (4000$2800 \mathrm{BP}$ ) (Horacek 1986). Thus, the northern race of garden dormouse probably recolonised this region from central and northern France, during the Holocene. Although some chromosomal rearrangements may occur on a short time scale, as was shown in the mouse $M$. domesticus (Britton-Davidian et al. 2000), the dormouse chromosomal races match the mtDNA genetic lineages that differentiated long before the Quaternary glaciations, about 4.2 \pm 1 Myr ago (Perez et al. 2012). Therefore, E. quercinus does not show a pattern of postglacial recolonisation of northwestern Europe from the refuge populations in Iberia or Italy. During the last ice age, the northern race may have been repelled by the Iberian race during its expansion towards the north, or it may have found a suitable refuge in the lower part of the Rhone valley between Montpellier, Lyon and Cannes, for which no karyotypic information is yet available. This last scenario would suggest that the northern race may be better adapted to the cooler summers of the Atlantic climatic conditions than the Iberian race. Indeed, during the very last Weichselian period, garden dormouse fossil remains were found (Vaucluse, Older Dryas, Haute Loire and Gard: last Vistulian) in association with Artic lemmings (Dicrostonyx torquatus) (Crégut-Bonnoure and Paccard 1997; Kowalski 2001) and were found in the same locality for long periods of time during which the climate switched from cold (Saalian) to warmer (Eemian), and again colder episodes (Weichselian) (Soyons, Ardèche; Defleur and Desclaux 1997). Therefore, this race had to differentiate north of the classical refuges for temperate species.

Acknowledgments This research was funded by the Fundação para a Ciência e a Technologia (Ministerio da Ciência e da Tecnologia), project no. POCTI/BSE/36626/99. R. Libois held a scholarship in the Departamento de Zoológia e Antropológia, Museu Nacional de Historia Natural, Universidade de Lisboa, Rua da Escola Politécnica, 58, P 1269-102, Lisboa, Portugal. Thanks are due to Dr. C. Nieberding who provided comments for improving the discussion, Mrs. R. Green for improving the English language, Dr. T. Kervyn for designing the map, C. Bouchardy, F. Bssaibis, R. Callejon, H. Destouches, F. Leboulenger, F. Léger, Fl. and Fr. Libois and C. Nappée for their assistance in the field and to the Belgian Fonds National de la Recherche Scientifique which funded RML for a short stay in France (réf. V3/5/134-BT.6281).

\section{References}

Antoine P, de Beaulieu JL, Bintz P, Brugal JP, Brulhet J, Girard M, Guadelli JL, Morzadec-Kerfourn MT, Petit-Maire N, RenaultMiskovski J, Roblin-Jouve A, van Vliet-Lanoë B, Vigne JD (1999) Notice explicative: La France pendant les deux derniers extrêmes climatiques. Variabilité naturelle des environnements. ANDRA/CNF-INQUA, pp. 68

Arroyo-Nombela JJ, Rodriguez-Murcia C, Delibes M, Hiraldo F (1982) Comparative karyotype studies between Spanish and French populations of Eliomys quercinus L. Genetica 59:161-166

Baker RJ, Haiduk MW, Robbins LW, Cadena A, Koop BF (1982) Chromosomal studies of South American bats and their systematic implications. Spec Publ Pymatuning Lab Ecol 6:303-327

Blondel J (1995) Biogéographie: Approche écologique et évolutive. Masson, Paris, p 297 
Britton-Davidian J, Catalan J, Ramalhinho MG, Ganem G, Auffray JC, Capela R, Biscoito M, Searle JB, Mathias ML (2000) Rapid chromosomal evolution in island mice. Nat 403:158

Britton-Davidian J, Catalan J, Lopez J, Ganem G, Nunes AC, Ramalhinho MG, Auffray JC, Searle JB, Mathias ML (2007) Patterns of genic diversity and structure in a species undergoing rapid chromosomal radiation: an allozyme analysis of house mice from the Madeira archipelago. Hered 99(4):432-442

Chaline J (1972) Les rongeurs du Pléistocène moyen et supérieur de France. Cah Paléontol CNRS, Paris, p 410

Corbet GB (1978) The mammals of the Palaearctic region: a taxonomic review. British Museum (Natural History), London

Crégut-Bonnoure E, Paccard M (1997) La faune à Saiga tatarica de Chinchon 1 (Saumanes, Vaucluse). Quaternaire 8(4):391-407

Cristaldi M, Canipari R (1976) À propos de la caryologie du lérot (Eliomys quercinus). Mammalia 40:475-488

Deffontaine V, Libois R, Kotlik P, Sommer R, Nieberding C, Paradis E, Searle JB, Michaux J (2005) Beyond the Mediterranean peninsulas: evidence of European glacial refuges of a forest mammal species, the bank vole (Clethrionomys glareolus). Mol Ecol 14:1727-1739

Defleur A, Desclaux E (1997) Étude préliminaire des micromammifères de la Baume Moula-Guercy à Soyons (Ardèche, France). Systématique, biostratigraphie et paléoécologie. Quaternaire 8:213-223

Diaz de la Guardia RS, Ruiz-Girela M (1979) The chromosomes of three Spanish subspecies of Eliomys quercinus (Linnaeus). Genet 51:107-109

Dutrillaux B, Aurias A, Lombard M (1979) Présence de chromosomes communs chez un rongeur (Eliomys quercinus, Lérot) et chez les primates. Ann Genet 22:21-24

Ellerman JR, Morrison-Scott TCS (1951) Checklist of Palaearctic and Indian mammals 1758 to 1946. British Museum (Natural History), London

Fauquette S, Suc JP, Guiot J, Diniz F, Feddi N, Zheng Z, Drivaliari A, Bessais E (1998) Végétation et climat en Méditerranée occidentale au Pliocène basal $(5,32-5 \mathrm{Ma})$ d'après les données polliniques. Ecologia Mediterr 24(1):89-100

Filippucci MG, Kotsakis T (1994) Biochemical systematics and evolution of Myoxidae. Hystrix (ns) 6:77-97

Filippucci MG, Simson S, Capanna E, Nevo E (1988a) The chromosomes of Israeli garden dormouse, Eliomys melanurus Wagner, 1840 (Rodentia, Gliridae). Boll Zool 55:31-33

Filippucci MG, Civitelli MV, Capanna E (1988b) Evolutionary genetics and systematics of the garden dormouse, Eliomys Wagner, 1840. 1. Karyotype divergence. Boll Zool 55:35-45

Filippucci MG, Rodino E, Nevo E, Capanna E (1988c) Evolutionary genetics and systematics of the garden dormouse, Eliomys Wagner, 1840. 2. Allozyme diversity and differentiation of chromosomal races. Boll Zool 55:47-54

Filippucci MG, Catzeflis F, Capanna E (1990) Evolutionary genetics and systematics of the garden dormouse, Eliomys Wagner, 1840 (Gliridae, Mammalia). 3. Further karyological data. Boll Zool $57: 149-152$

Gornung E, Bizzoco D, Colangelo P, Castiglia R (2010) Comparative cytogenetic and genetic study of two Italian populations of the garden dormouse Eliomys quercinus L. (Sciuromorpha: Gliridae). Ital J Zool 77:137-143

Graphodatsky AS, Fokin IM (1993) Comparative cytogenetics of Gliridae (Rodentia). Zool Zhur 72:104-113

Hewitt GM (1999) Postglacial recolonization of European biota. Biol J Linn Soc 68:87-112

Holden ME (1993) Family Myoxidae. In: Wilson DE, Reeder DAM (eds) Mammal species of the world. A taxonomic and geographic reference, 2nd edn. Smithsonian Institution Press, Washington, pp $763-770$
Horacek I (1986) Fossil records and chorological status of dormice in Czechoslovakia. Part I: Glis glis, Eliomys quercinus. Folia Mus Rerum Nat Bohem Occident 24:49-59

Kahmann H, Thoms G (1981) Über den Gartenschläfer (Eliomys) in nordafrikanischer Landern (Mammalia, Rodentia, Gliridae). Spixiana 4:191-228

Kotsakis T (1986) Elementi di paleobiogeographia dei mammiferi Terziari dell Italia. Hystrix 1:25-68

Kowalski K (2001) The Pleistocene rodents of Europe. Folia Quat 72:1-389

Krystufek B, Kraft R (1997) Cranial variation and taxonomy of the garden dormice (Eliomys Wagner, 1840) in the circum Mediterranean realm. Mammalia 61:411-429

Léonard A, Deknudt G, Mergeay M (1970) Les chromosomes du lérot (Eliomys quercinus L.). Acta Zool Pathol Antverp 50:55-60

Lopez-Garcia JM, Agusti J, Cuenca-Bescos G (2007) Catalogue of the late Quaternary Iberian mico-mammals (Rodentia, Eulipotyphla, Chiroptera) from the Museum de Geologia de Barcelona, Spain. Treb Mus Geol Barcelona 15:5-23

Matthey B, Renaud P (1937) Les chromosomes du lérot. Bull Soc vaud Sci nat 59:507-508

Michaux J, Libois R, Ramalhinho MG, Maurois C (1998) On the mtDNA restriction patterns variation of the Iberian wood mouse (Apodemus sylvaticus). Comparison with other west Mediterranean populations. Hereditas 129:187-194

Michaux JR, Magnanou E, Paradis E, Nieberding C, Libois R (2003) Mitochondrial phylogeography of the woodmouse (Apodemus sylvaticus) in the Western Palearctic region. Mol Ecol 12:685-697

Michaux J, Libois R, Paradis E, Filippucci MG (2004) Phylogeographic history of the yellow-necked fieldmouse (Apodemus flavicollis) in Europe and in the Near and Middle-East. Mol Phyl Evol 32:788-798

Miller GS (1912) Catalogue of the mammals of western Europe. British Museum (Natural History), London

Murariu D, Lungeanu A, Gavrila L, Stepan C (1985) Preliminary data concerning the study of the karyotype of Eliomys quercinus (Linnaeus, 1766) (Mammalia, Gliridae). Trav Mus Hist nat Grigore Antipa 27:325-327

Nadachowki A, Rzebik-Kowalska B, Kadhim AHH (1978) The first record of Eliomys melanurus Wagner, 1840 (Gliridae, Mammalia) from Iraq. Säugetierkdl Mitteil 26:206-207

Nader IA, Kock D, Al-Khalili AKD (1982) Eliomys melanurus (Wagner, 1840) and Praomys fumatus (Peters, 1878) from the kingdom of Saudi Arabia (Rodentia, Mammalia). Senckenbergiana Biol 63:313-324

Nieberding C, Libois R, Morand S, Douady C, Michaux JR (2005) Phylogeography of a Nematode (Heligmosomoides polygyrus) in the Western palaearctic region: persistence of Northern cryptic populations during ice ages? Mol Ecol 14:765-779

Niethammer J (1959) Die nordafrikanischen Unterarten des Gartenschläfers (Eliomys quercinus). Z Säugetierkde 59:35-45

Ognev SI (1963) Mammals of the USSR and adjacent countries: rodents, vol V. Israël Program Sci Transl, Jerusalem

Orsini P (1987) Le lérot. In: Les mammifères en Corse. Ed Parc nat rég Corse, Ajacciu, Gallia Prehistoire 26(suppl):99-101

Perez G Libois R, Nieberding C (2012) Phylogeography of the garden dormouse Eliomys quercinus in the Western Palearctic region. J. Mammalogy (in press)

Polyakov AV, White TA, Jones RM, Borodin PM, Searle JB (2011) Natural hybridization between extremely divergent chromosomal races of the common shrew (Sorex araneus, Soricidae, Soricomorpha): hybrid zone in Siberia. J Evol Biol 24(7):1393-1402

Ramalhinho MG, Libois R (2005) Karyotype of dormice, Eliomys quercinus from Tirol (Austria). Acta Therol 50:133-136

Renaud P (1938) La formule chromosomique chez sept espèces de Muscardinidae et de Microtinae indigènes. Rev Suisse Zool 45:350-383 
Sala B (1996) Dinaromys allegranzii n. sp. (Mammalia, Rodentia) from Rivoli Veronese (northeastern Italy) in a Villanyian association. Acta Zoologica Cracoviensia 39(1):469-472

Seabright MA (1971) A rapid banding technique for human chromosomes. Lancet 2:971-972

Storch G (1978) Familie Gliridae Thomas, 1897-Schläfer. In: Niethammer J, Krapp F (eds) Handbuch der Säugetiere Europas. Nagetiere I Akad Verlagsgesellschaft, Wiesbaden, pp 201-280

Taberlet P, Fumagalli L, Wust-Saucy AG, Cosson JF (1998) Comparative phylogeography and postglacial colonization routes in Europe. Mol Ecol 7:453-464

Veyrunes F, Catalan J, Tatard C, Cellier-Holzem E, Watson J, Chevret P, Robinson TJ, Britton-Davidian (2010) Mitochondrial and chromosomal insights into karyotypic evolution of the pygmy mouse, Mus minutoides, in South Africa. Chromosome Res 18:563-574

Vujosevic M, Filippucci MG, Blagojevic J, Krystufek B (1993) Evolutionary genetics and systematics of the garden dormouse, Eliomys Wagner, 1840. 4. Karyotype and allozyme analyses of E. quercinus dalmaticus from Yugoslavia. Boll Zool 60:47-51

Zima J, Macholan M, Filippucci MG (1994) Chromosomal variation and systematics of Myoxids. Hystrix 6:63-76

Zima J, Macholan M, Andera M, Cerveny J (1997) Karyotypic relationships of the garden dormouse (Eliomys quercinus) from central Europe. Folia Zool 46:217-221 